\title{
Study of high-pressure abrasive water jet capacity indices for steep cutting of steels
}

\author{
Badania wskaźników zdolności skrawnej \\ wysokociśnieniowego strumienia wodno-ściernego \\ przy cięciu krzywoliniowym stali
}

RAFAŁ KUDELSKI *

DOI: https://doi.org/10.17814/mechanik.2017.11.161

\begin{abstract}
Quality of the technological part is one of the major problems of modern machine manufacturing. In many cases, components are manufactured from new construction materials with specific properties that are considered difficult to machining applying conventional technologies. Hence, to search for new technologies, including high-pressure abrasive water jet cutting in the context of the S355J2H steel elements manufacture, while maintaining the quality requirements of the machining, is the need. The results of tests on the accuracy of components made of $\mathbf{S} 355 \mathrm{~J} 2 \mathrm{H}$ steel are presented as dependent on the water jet pressure, cutting feedrate and the amount of abrasive dozed, with constant element thickness. The accuracy of the design measure - regardless of dimensional accuracy - was the magnitude of the lateral sagging of the cut workpiece resulting from the specific mechanism of water jet removal mechanism. KEYWORDS: technological quality, steel S355J2H, workpiece cutting, abrasive jet
\end{abstract}

The cut gap, the formation of which is a phenomenon of the material removal process at abrasive water-jet, does not find counterparts in known machining practices. The difference in the process of material removal using mechanical tool with the high form force of the blade does not allow the use of known models of cutting interpretation in the problem of material destruction during water jet machining. Hence, there is an incomplete knowledge of the process of controlling the abrasive water-jet cutting in a number of specific issues and the need for experimental verification of the assumed indicators of technological quality of workpieces.

The energy parameters of the water jet $[6,8]$ depend on the initial conditions, i.e. water pressure and the path that the jet travels through the air from the moment of leaving the water nozzle to abrasive grains in the mixing chamber. In this way, the jet expands as a result of cavitation to release the steam and the ambient air contained in water [6] and a significant aeration in the air, contributing to the multiphase of water jet with abrasive [2, 4]. This leads to the formation of a typical cut slit characterized applying parameters indicated in fig. 1.

\footnotetext{
* Dr inż. Rafał Kudelski (kudelski@agh.edu.pl) - AGH Akademia Górniczo-Hutnicza
}

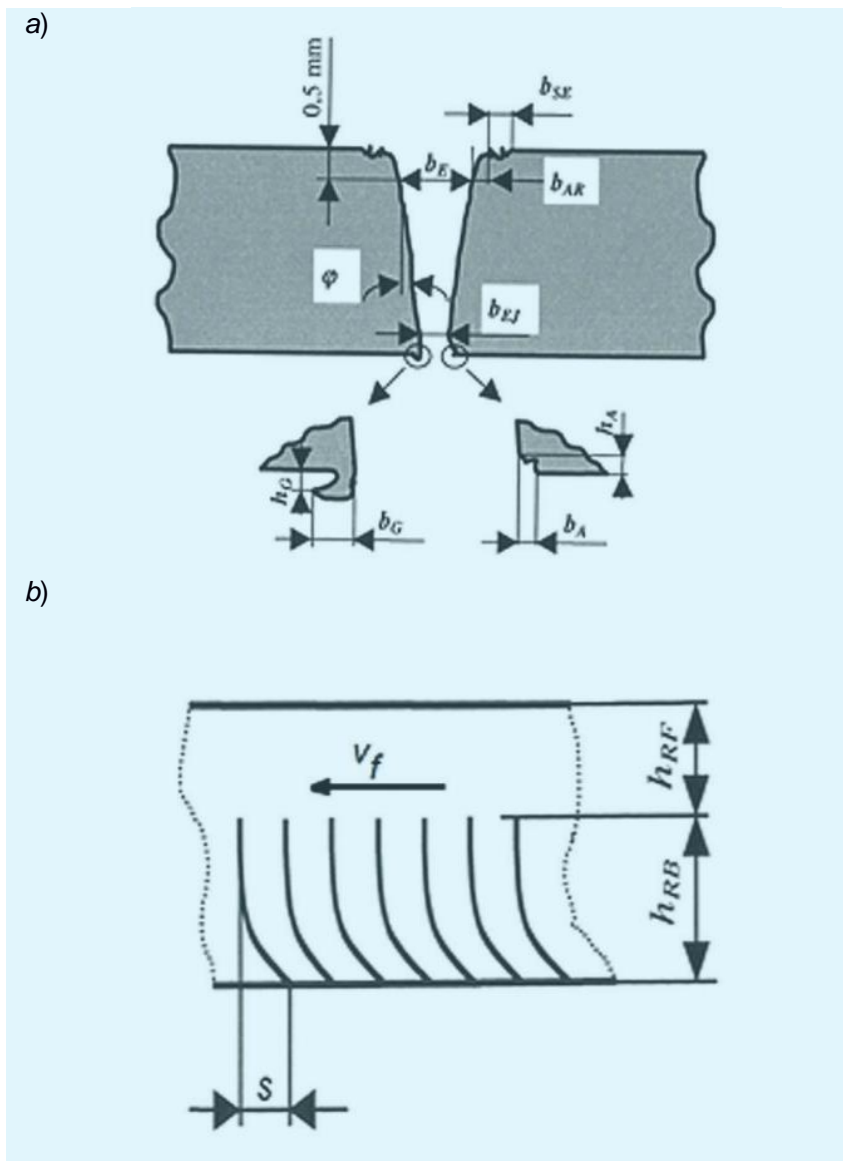

Fig. 1. Cutting slit: a) cross-section according to VDI 2906 with positive convergence, $b$ ) longitudinal section in the feed direction [10]

As can be seen in the pictures of the cut slit shown in fig. 1, removing the material with a abrasive water-jet is a complicated process. A complex transverse profile of the cut is achieved, the formation of which can be explained by effects of turbulence flow in the gap, and transverse to the feed direction of water jet expansion. From the observation of the cut surface, it indicates that increasing the thickness of the workpiece $[1,2,5,7]$ creates favorable conditions for more turbulent flow of the multiphase fluid in the gap due to the curvature of the lower region of the slit (fig. 1b). As a result, there is a deviation of the trajectory of the abrasive water-jet of the size opposite to the return of the feed vector $v_{f}$ - which is shown in fig. $1 b[8,9]$. 
The amount of deviation $s$ determined in a longitudinal section of the slit - with a predetermined thickness of the workpiece and a certain type of material - is dependent on the cutting capacity of abrasive water-jet [4].

The maximum thickness of the cut material for the entire permissible range of variation of the mentioned parameter groups, corresponding to the maximum cutting capacity, may be determined by the concept of the cutting capacity of abrasive water-jet.

The paper presents results of the research upon the influence of abrasive water-jet cutting capacity on the cutting quality indicators of the elements with shapes indicated in fig. 2.

Examination of selected quality indicators was conducted to determine the possibility of accurate treatment of abrasive water-jet and to identify defects in the shape of the workpiece. Due to the possible use of this technology for the machining, the utmost importance is put to rating error roundness of the respective parts of the object - both from the input flow of abrasive water-jet, as well as the output from the object - and errors of nonperpendicularity of the workpiece walls with respect to the base plane (fig. 2).

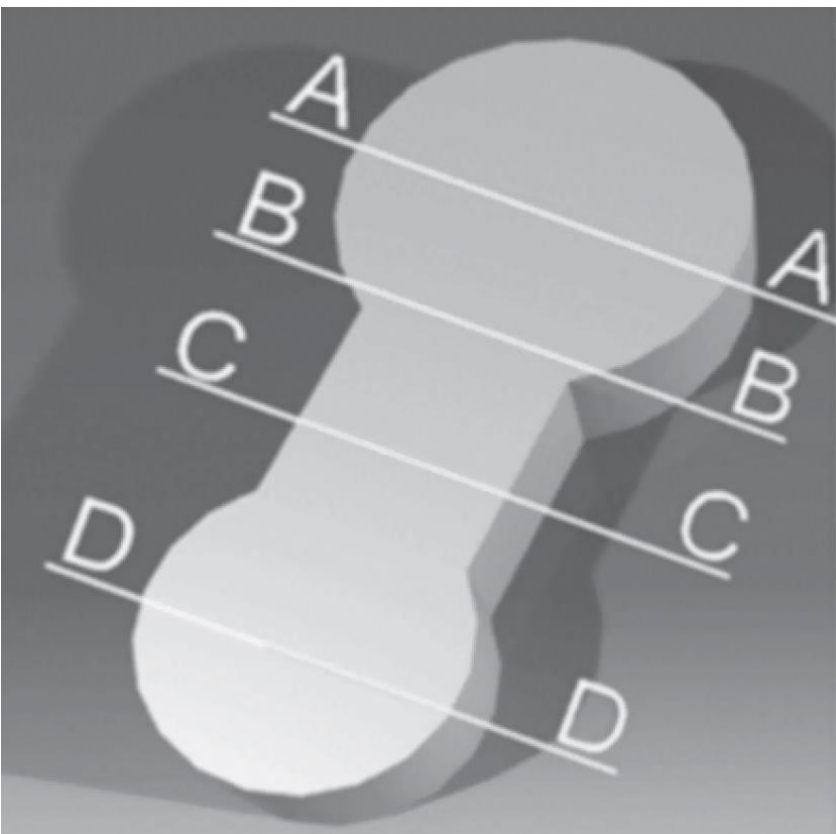

Fig. 2. Element of $\mathrm{S} 355 \mathrm{~J} 2 \mathrm{H}$ steel with marked zones $(A, B, C, D)$ for testing the non-perpendicularity error

\section{Experimental study}

Experimental results of the $5355 \mathrm{~J} 2 \mathrm{H}$ steel cutting technology quality indices were performed on a Ridder water-jet cutting machine with a pre-abrasive grinding wheel [4].

On the basis of the variation of the cutting potential in the cutting of the steel $\mathrm{S} 355 \mathrm{~J} 2 \mathrm{H}$, for a workpiece with a thickness of $25 \mathrm{~mm}$, the maximum feedrate of $v_{f}=1.7$ $\mathrm{mm} / \mathrm{s}$ was determined at a pressure not less than $p=280$ $\mathrm{MPa}$ and the abrasive flow was not less than $q=6.5 \mathrm{~g} / \mathrm{s}$. The specified parameters provide the minimum cutting capacity of the abrasive water-jet to make an element of such material. However, to obtain a complete picture of the dependency, the range of feedrate variability in the range $v_{f}=0.083 \div 1.7 \mathrm{~mm} / \mathrm{s}$ was extended in the second part of the study, providing greater than the required cutting capacity. Thus, the range of variability of decision parameters in the ranges $v_{f}=0.083 \div 1.7 \mathrm{~mm} / \mathrm{s}, p=$
$180 \div 380 \mathrm{MPa}$, abrasive flowrate $q=3 \div 10 \mathrm{~g} / \mathrm{s}$, was selected for further tests.

In this part of the experimental research realized in accordance with the PS/DS.-P:L(L) [3] plan, a $25 \mathrm{~mm}$ thick steel plate was cut in accordance with the parameters specified in the experimental plan. The object of the shape indicated in fig. 2 was characterized by 2 sections of the circular profile, respectively with radii $R 15$ and $R 20$, connected by a straight line. Measurements of selected execution errors were performed on a Global Performance measuring machine coordinate system with PC DMIS software. Taking into account the complex trajectory of the abrasive water-jet in the material (fig. 1), characteristic areas of the object (zones $A, B, C, D$ in fig. 2) were selected, where there was the greatest error in shape due to curvature $s$ of abrasive water-jet at the exit of the object.

The magnitude of the error $\Delta$ as the radial difference of the object fragments determined at the input and output of the high pressure jet of the object (at the bottom of the object) is related to the interaction of the abrasive waterjet with the material and remains in direct dependence on its machinability. However, deviations of the shape of the object, determined by the non-perpendicularity of its lateral surface to the base, and in particular, errors of the profile in the circular sections of the profile, will result from the interaction of the high pressure jet with the object in the area of the work gap.

Exemplary deviations of the object's curvature after abrasive water-jet, obtained in the study, are presented in the table.

TABLE. Exemplary deviation of the object roundness after cutting with abrasive water-jet

\begin{tabular}{|l|c|c|c|}
\hline Sample & S3 & S5 & $S 11$ \\
\hline $\begin{array}{l}\text { Pressure, } \\
\mathrm{MPa}\end{array}$ & 220 & 220 & 280 \\
\hline $\begin{array}{l}\text { Feedrate, } \\
\mathrm{mm} / \mathrm{min}\end{array}$ & 52,8 & 17,2 & 5 \\
\hline $\begin{array}{l}\text { Abrasive } \\
\text { consumption, } \\
\mathrm{g} / \mathrm{s}\end{array}$ & 4,42 & 8,3 & 6,5 \\
\hline $\begin{array}{l}\text { Deviation, } \\
\mathrm{mm}\end{array}$ & $\begin{array}{l}\Delta R 15=1,04 \\
\Delta R 20=0,68\end{array}$ & $\begin{array}{l}\Delta R 15=0,03 \\
\Delta R 20=0,13\end{array}$ & $\begin{array}{l}\Delta R 15=-59 \\
\Delta R 20=-49\end{array}$ \\
\hline
\end{tabular}

The results show that, similar to the water pressure, the cut results are strongly influenced by the circular parts of the workpiece profile, as illustrated in the Table for measured results of circular workpieces of radius $15 \mathrm{~mm}$ $(R 15)$ and $20 \mathrm{~mm}(R 20)$, respectively.

The results indicate that in some cutting parameters, the diameter of the circular object fragment at its base is greater than the diameter of the object in the upper part (at the jet entrance) and the difference is in the order of 1 $\mathrm{mm}$. In such cases, it can be concluded that a classic slit cleavage with positive convergence is formed in some conditions, especially at higher cutting speeds, as shown in fig. 1. However, analysis of the full range of test variables (Table, sample S11) indicates the possibility of a slit with a negative convergence, in which case the respective diameters of the circular object fragments at the base become smaller than the diameter at the jet entrance into the material. A slit with negative convergence can be formed under high cutting capacity due to low feedrate, a large amount of dozed abrasive at high water pressure or due to incorrect selection of all 3 parameters. With regard to the results obtained for steel machining, it can be concluded that such cases occur when the abrasive water-jet is redundant in relation to the 
required cutting capacity. In the case of cutting steel with parameters corresponding to the cutting potential (table, sample S3), a classical slit with positive convergence is obtained. a)

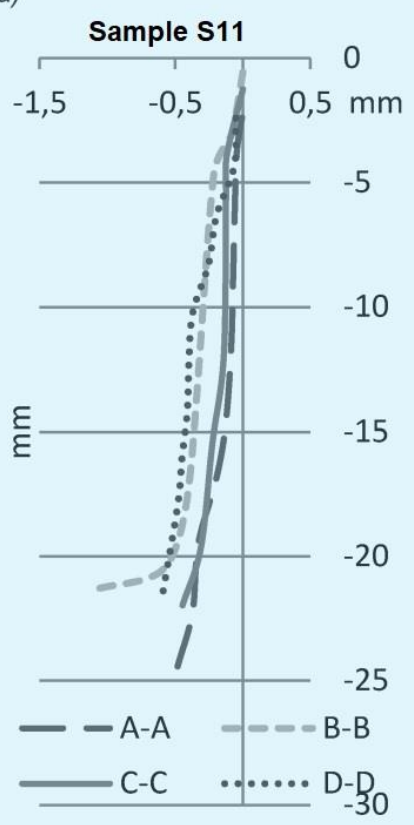

b)

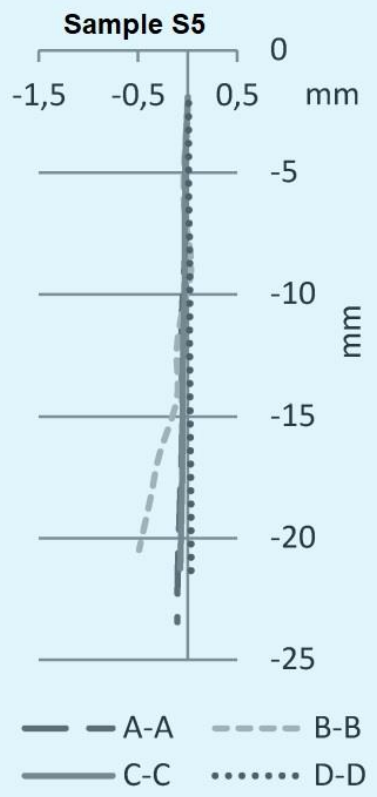

Fig. 3. Side surface shape defects for samples: a) $S 11$ and b) $S 5$ in designated zones $A, B, C, D$

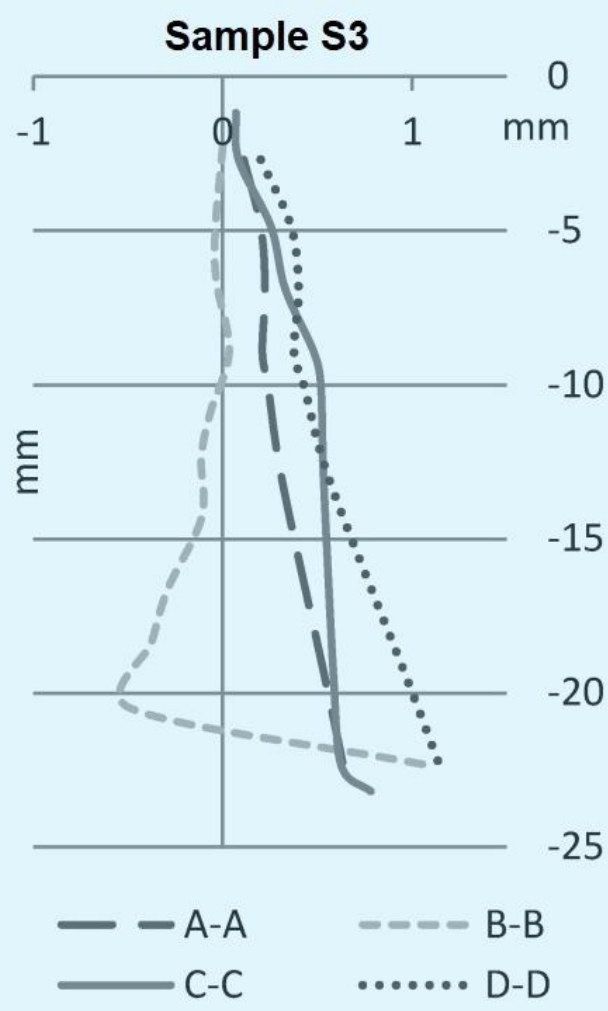

Fig. 4. Side surface shape defects for sample $S 3$ in the marked zones $A, B, C, D$

This type of dependence has been confirmed in the results of the non-perpendicularity tests on the lateral surface of the workpiece as shown in fig. 3 and fig. 4 . They indicate that the inaccuracy of a complex shape defined by the non-perpendicularity of the side surface depends not only on the curvature of the workpiece, but also on the type of transitions between curves. The greatest errors of this type occur in the lower part of the object, when passing the curvilinear path to the straight line of the cutting track (zone $B-B$ fig. 3 and fig. 4).

An exception is the cut gap during steel machining, which may have a positive or negative convergence, which has a significant effect on the errors of the workpiece. A significant finding of the study is the possibility of obtaining a slit with parallel walls (excluding the undercutting of the element in zone $B-B$ ), which results in the most accurate machining of the steel element S355J2H (fig. 3, sample S5).

\section{Conclusions}

The abrasive water-jet machining of steel in the aspect of complexity and accuracy of the workpiece is characterized by significant variations of such accuracy indices such as the inclination of the workpiece walls, curvature errors of the arch parts (if any), and the appearance of characteristic errors caused by the trajectory of the high-pressure jet in the exit zone of the workpiece. Errors of this kind are particularly large in contour discontinuity areas of the object, e.g. in places where straight lines are cut into curved lines. A characteristic feature of cutting the $5355 \mathrm{~J} 2 \mathrm{H}$ steel elements using high-pressure abrasive water-jet is the possibility of formation of the cut slit with positive or negative convergence depending on the choice of cutting capacity of the jet.

Proper selection of parameters (cutting capacity) allows cutting with a zero convergence slit. In this situation, the assessment of technological quality of the workpiece after water-jet machining is particularly complex due to the simultaneous variability and interdependence of the accuracy of the workmanship and surface roughness. The presented dependencies clearly indicate the dependence of the shape errors on the workpiece itself, the cutting conditions and the type of material. In the case of materials like steel S355J2H, this relationship is evidenced in a particular way.

\section{The research was carried out under the agreement} 15.11.130.603

\section{REFERENCES}

1. Begic-Hajdarevic D., Cekic A., Mehmedovic M., Djelmic A. „Experimental study on surface roughness in abrasive water jet cutting”. Procedia Engineering. 100 (2015): pages 394-399.

2. Borkowski J., Sutowska M. „The quality of surface shaped by abrasivewaterjet”. Unconventional and Hydrojetting Technologies. ISSN 02397129. Koszalin 2009, pages 259-272.

3. Górecka R. „Teoria i technika eksperymentu”. Kraków: Politechnika Krakowska, 1998.

4. Kudelski R. „Badania wskaźników zdolności skrawnej wysokociśnieniowego strumienia wodno-ściernego w procesach cięcia". Rozprawa doktorska. Kraków: AGH 2016.

5. Loschner P., Jarosz K., Niesłony P. „Investigation of the effect of cutting speed on surface quality in abrasive water jet cutting of $316 \mathrm{~L}$ stainless steel". Procedia Engineering. 149 (2016): pages 276-282.

6. Momber A., Kovacevic R. „Principles of Abrasive water jet Machining”. Berlin-Heilderberg-New York: Springer Verlag, 1997.

7. Sutowska M. „Wpływ warunków procesu cięcia wysokociśnieniową strugą wodno-ścierną na kształt śladów obróbkowych". ATMiA. 4, 31 (2011).

8. Wantuch E., Kot R. „Problem dokładności odwzorowania toru krzywoliniowego przy obróbce wysokociśnieniowym strumieniem wodnościernym". XXVI Naukowa Szkoła Obróbki Ściernej. Łódź, 2003, pages 329-337.

9. Wantuch E., Nieciąg H., Kudelski R. „Problematyka krzywoliniowego cięcia wysokociśnieniowym strumieniem wodno-ściernym elementów ze stopu Al”. XXXVI Naukowa Szkoła Obróbki Ściernej NSOŚ. Baranów Sandomierski, 18-20 września 2013.

10. VDI-Richtlinien: VDI2906, Abrasiv - Wasserstrahlschneiden, 1994. 